\title{
Redaktören har ordet
}

Julljusen tänds i de snöfria sydsvenska bygderna medan Linnéuniversitetets anställda febrilt avverkar de sista göromålen innan långhelgen. Till dessa göromål hör av hävd årets sista nummer av HumaNetten som denna gång har ett tydligt internationellt fokus i tid och rum. Förvånande är inte detta. Fakulteten för konst och humaniora (eller kort och gott FKH) är sedan flera år hemvist för två av de centers of excellence som etablerats på Linnéuniversitetet och producerar kunskap i hög fart, ofta på engelska. Två av artikelskribenterna har koppling till Center for Concurrences in Colonial and Postcolonial Studies, eller i korthet Concurrences (på svenska Samtidigheter) under det att den tredje studerat för forskare verksamma inom Intermedial Studies (IMS). De bägge centrumbildningarna har varit verksamma med konferenser, forskarutbildning och publiceringsprojekt och därmed hjälp till att sätta Linnéuniversitetet på kartan.

I detta nummer beskriver religionsvetaren Torsten Löfstedt i sin studie "Establishing authority in Spiritual Warfare literature" hur föreställningar om en ond andevärld har nått viss spridning bland pingströrelser och karismatiska kristna. Vissa författare hävdar sig ha fått kunskap om ondsinta makter som har satt sig i kontroll av institutioner, städer och nationer, och anvisar medel för att bekämpa dessa. Som Löfstedt påpekar har dessa strömningar mycket gemensamt med New Age trots sina bedyranden om motsatsen. Vi får följa hur författarna till texter om andlig krigföring söker bevisa sin auktoritet och kunskap inför omvärlden. Historikern Stefan Amirell analyserar i sin text "Civilizing pirates: Nineteenth century British ideas about piracy, race and civilization in the Malay Archipelago" en mindre spirituell men så mycket mer fysiskt påtaglig motståndare: pirater. Den malajiska övärlden var under 1800-talet hemsökt av inhemska sjörövare och utgjorde ett problem inte minst för de europeiska kolonisatörer som var i färd att skaffa sig fotfäste i Sydöstasien. Amirell visar på de skiftande europeiska attityderna till pirater och hur man borde handskas med dem, och hur detta påverkade den förda kolonialpolitiken som i sig kunde vara nog så brutal. Våldsamma scener analyseras också av litteraturvetaren Anneliese Fältström i sin studie av en roman av den kinesiske nobelpristagaren Mo Yan, "Filmens tekniker som litterär metod att gestalta våld och kroppslighet som känns mot huden: En medialitetsanalys av Mo Yans roman Ximen Nao och hans sju liv". Hon gör här en analys av romanens strategier där hon fördjupar sig i scener som innefattar kroppslighet och våld. Detta blir hos Mo Yan en strategi för att framkalla en kroppslig reaktion hos läsaren, i analogi med filmens tekniker. Intressant läsning tillönskas under juluppehållet.

För redaktionens räkning

Hans Hägerdal 